\title{
NOte In homage to professor pedro paulo A. FUNARI
}

Julio Cesar Magalhães de Oliveira ${ }^{1}$

I started my graduation major in History at the State University of Campinas in 1995 and I had classes with Professor Pedro Paulo A. Funari since the very first semester of that year. In great measure, if I have dedicated my career to studying Ancient History, I owe it to that course the first among many of his undergraduate and graduate courses that I attended in the following years. I remember how nice it felt to listen to his expository classes, which would always present us a field of problems, rather than a finished narrative. I also remember the group discussions, which always engaged us to produce our very own line of thoughts. And it was through all this that I was introduced to a different and (for a young student) stimulating form of thinking the writing of History - not as a mimesis of the past, but as a diegesis, the junction of sparse elements, a construction that cannot be dissociated from the present. Today I can see that much of who I try to be as a teacher is a reflex of the example he gave us, from his stance in class to the very conception of what a class really is.

It was in that very same year that I first read his book Cultura popular na Antiguidade Clássica - not the Brazilian edition published in 1989, but the Spanish translation published in 1991 as La cultura popular en la Antigüedad Clásica. For me, like for many other of his students who started our researches in the 90's, this unconventional book became a stimulus to re-think Ancient History from a bottom-up perspective. Written in the context of the re-democratization of the Brazilian society, at a time of widening theoretical debates and the emergence of another ethical-political stance among Brazilian historians, the book broke with the worst legacy to Ancient History of the authoritarian and repressive regime of 1964-1985: "the stigma of an area of historical knowledge marked by intellectual alienation, by indifference to the problems of the present, and by its elitism and conservatism" (Glaydson Silva). Valuing the popular cultural elaborations through the Pompeian graffiti, the book proposed a vision of History less partial and less restricted to the topmost strata of society. Aimed at a broad audience, it also deliberately broke

\footnotetext{
1 Assistant Professor, Universidade de São Paulo, São Paulo, Brasil. E-mail: jcmagalhaesoliveira@gmail.com
} 
away with the elitism so characteristic of the discipline. Particularly daring was Funari's proposal of not only translating but also of recreating in our cultural context the graffiti of Pompeii in an attempt of bringing the reader closer to this distant world. Yet the large number of reviews published in specialized journals between 1989 and 1994 also shows the impact that the book had on the academy itself. Indeed, it would not be an exaggeration to say that the book became a milestone, perhaps the main turning point in the development of a specifically Brazilian tradition of studies on the so-called "subaltern groups" in antiquity.

This was a constant inspiration for me, even though, since my undergraduate research project, I had turned not to the direct testimony of the subalterns (such as the graffiti), but to a reading against the grain of the textual sources of an intellectual man - the letters and sermons of Saint Augustine. Thinking that education (at all its levels) is nothing but the development of a student's self-awareness, Professor Funari has always encouraged me to make my own choices of problems and subjects of research. But to this freedom of choice also corresponded his constant questioning, which forced me to underscore on stronger and more theoretical bases all my statements and opinions. I remember that since our first meeting, when he accepted to supervise my work, he commented on the challenges and compensations of making Ancient History in Brazil. Although highlighting the advantages derived from the peripheral Brazilian situation, which allows us to propose themes and issues in a very different way from those prevalent in the hegemonic centers, Professor Funari has always encouraged his students to dialogue with the universal science, to scrutinize the written sources in their original language, to know and confront different historiographic traditions. I am particularly indebted to him for making me see, throughout my years as undergraduate and master's student, the importance of confronting different types of sources, of considering the archaeological documentation and of guarding the critical spirit before every historiographic discourse. These are the characteristics that have made of Professor Pedro Paulo Funari one of the main leaders in the area of Ancient History in Brazil and someone who decisively contributed to raise this area of historical knowledge to the level that it has reached today.

It would be long to mention in a note the whole impact of his multifaceted work, written in several languages and in an intense dialogue between Archeology, History, Education, Heritage, Philosophy, Letters and History of Art. But it is worth emphasizing his effort to create institutional bases for the development of Ancient History in an 
interdisciplinary perspective. It was thanks to his initiative and that of Prof. Hector Benoit that the Center of Ancient Thought (CPA) was founded in that same year of 1995, when I entered the university. The CPA biennial conferences continue to bring together researchers of Ancient History, Classical Archeology, Ancient Philosophy and Classical Letters in a rare exchange of experiences among the practitioners of these disciplines. Professor Funari's activity in groups and research centers have always been guided by this same commitment to lay the foundations for the future development of research by the generations that will succeed him. The recent donation by Professor Funari of all his bibliographical and documentary collection to the Department of History of the Federal University of São Paulo (UNIFESP) is yet another example of his greatness, his generosity and his conviction that knowledge should not be the property of the privileged but an instrument of collective transformation. It is an honor for me to participate in this just homage and it is a pleasure to express my gratitude to a teacher and friend whom I owe so much of what I am as a researcher and teacher today. 